Original Article

\title{
Body composition, growth performance and enzyme activities of Labeo rohita fed different commercial fish feeds
}

\author{
Composição corporal, desempenho de crescimento e atividades enzimáticas de \\ diferentes alimentos para peixes comerciais alimentados por Labeo rohita
}

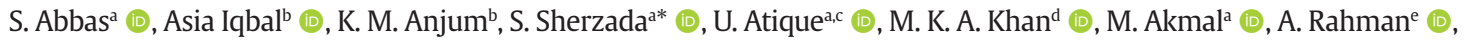

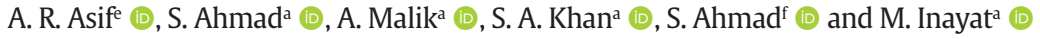 \\ aUniversity of Veterinary and Animal Sciences, Department of Fisheries and Aquaculture, Lahore, Pakistan \\ bUniversity of Veterinary and Animal Sciences, Department of Wildlife and Ecology, Lahore, Pakistan \\ 'Chungnam National University, Department of Bioscience and Biotechnology, Daejeon, South Korea \\ dUniversity of Okara, Department of Zoology, Okara, Pakistan \\ eUniversity of Veterinary and Animal Sciences, Department of Animal Sciences, Jhang Campus, Jhang, Pakistan \\ University of Veterinary and Animal Sciences, Faculty of Animal Production and Technology, Department of Poultry Production, Lahore, Pakistan
}

\begin{abstract}
We have evaluated the effects of different fish feeds on the body composition, growth, and enzyme activities of Labeo rohita (Rohu). In total, 240 fishes between the average weights of $24.77 \pm 2.15 \mathrm{~g}$ were studied. The treatments were applied in a completely randomized design, with 4 treatments of 60 fishes each. Treatments consisted of four different fish feeds [Oryza (T1), AMG (T2), Aqua (T3), and Supreme (T4)]. Body composition, growth performance, and enzyme activities were evaluated. There was a significant variation in performance of fishes fed with different type of feed; as fishes having Oryza feed showed the highest weight gain, specific growth rate (SGR), and best feed conversion ratio (FCR) as compared to other groups that were considered to be significant $(\mathrm{P} \leq 0.05)$. High net weight gain was obtained in T4 when compared with T2 and T3. FCR value of T4 was less than T1 but higher than T2, T3 and T2, which showed the lowest values. The specific growth rate was recorded as average in T4, but T2 led a high SGR than T3. Similarly, crude protein level and digestive enzymes activity was recorded significantly highest in fed with Oryza (T1) as compared to AMG (T2), Aqua (T3), and Supreme (T4). Water quality parameters were recorded significant in all treatments except $\mathrm{pH}$ and $\mathrm{DO}$ of treatment (T1), significantly different from other treatments. It was concluded that Rohu (Labeo rohita) could show a promising growth rate and protease enzyme activity when fed with the Oryza feed of $25 \%$ protein.
\end{abstract}

Keywords: commercial fish feeds, growth, body composition, enzyme activity, Rohu.

\begin{abstract}
Resumo
Avaliamos os efeitos de diferentes alimentos para peixes em relação à composição corporal, crescimento e atividades enzimáticas de Labeo rohita (Rohu). No total, foram estudados 240 peixes com pesos médios de $24,77 \pm 2,15$ g. Os tratamentos foram aplicados em delineamento inteiramente casualizado, com quatro tratamentos de 60 peixes cada. Os tratamentos consistiram em quatro alimentos diferentes para peixes: Oryza (T1), AMG (T2), Aqua (T3) e Supreme (T4). Foram avaliados a composição corporal, o desempenho de crescimento e as atividades enzimáticas. Houve uma variação significativa no desempenho dos peixes alimentados com diferentes tipos de ração. Peixes com alimentação Oryza apresentaram maior ganho de peso, taxa de crescimento específico (SGR) e melhor taxa de conversão alimentar (FCR) em comparação com outros grupos que foram considerados significativos $(P \leq 0,05)$. Elevado ganho de peso líquido foi obtido em T4 quando comparado com T2 e T3. O valor da FCR de T4 foi menor que $\mathrm{T} 1$, mas maior que T2 e T3, que apresentaram os menores valores. A taxa de crescimento específico foi registrada como média em T4, mas T2 teve uma SGR alta do que T3. Da mesma forma, o nível de proteína bruta e a atividade das enzimas digestivas foram registrados significativamente mais altos nos peixes alimentados com Oryza (T1) em comparação com AMG (T2), Aqua (T3) e Supreme (T4). Os parâmetros de qualidade da água foram registrados como significativos em todos os tratamentos, exceto $\mathrm{pH}$ e OD do tratamento (T1), significativamente diferente dos demais tratamentos. Concluiu-se que Rohu (Labeo rohita) pode apresentar uma taxa de crescimento promissora e atividade da enzima protease quando alimentado com Oryza de $25 \%$ de proteína.
\end{abstract}

Palavras-chave: alimentos para peixes comerciais, crescimento, composição do corpo, atividade enzimática, Rohu.

*e-mail: shahid.sherzada@uvas.edu.pk

Received: March 29, 2021 - Accepted: June 7, 2021

This is an Open Access article distributed under the terms of the Creative Commons Attribution License, which permits unrestricted use, distribution, and reproduction in any medium, provided the original work is properly cited. 


\section{Introduction}

Aquaculture is a system that produces various aquatic species for human utilization (FAO, 2009; Batool et al., 2018; Iqbal et al., 2020; Rahman et al., 2020). Aquaculture is mainly divided into extensive and intensive types based on water quality and feed inputs (Ray et al., 2021; Jewel et al., 2020). The yield of a comprehensive system is meagre due to a lack of knowledge, required facilities, poor water quality and its management, and not exploring the locally available cheap feed ingredients (Atique et al., 2020a; Bae et al., 2020). However, intensive aquaculture applies the latest pond structure technologies, feeding, stocking density, etc., for the high yield of aquatic organisms (Haider et al., 2018; Iqbal et al., 2020a, b). This system is progressing day by day all around the world (Ackefors et al., 1994). Aquaculture yield showed a remarkable increase during the last few years. For the continuous progress of aquaculture, nutrition and feeding of fish are essential factors. That's why it is necessary to maintain the feed and fertilizer resources to better aquaculture progress (Hasan, 2001; Ahmad et al., 2020; Khan et al., 2018).

Protein is the major component in the fish flesh, that's why protein is the main component of the fish diet. Dietary protein conversion into tissue protein is a significant component in the fish culturing system (Webster and Lim, 2002; Hayat et al., 2020b). Protein plays a pivotal role in the proper functioning, growth, and makeover of new body protein. The price of feed depends upon the percentage of protein in fish feed. Feed proved to be economical if all protein present in feed converted to body protein and the small portion used in catabolism (Gauquelin et al., 2007).

The strengthening of fish culture is driving the way towards the utilization of artificial feeds. Crude protein is the most expensive part of the feed and vital in fish's growth progress (Luo et al., 2004). The reduction in feed price plays a crucial role in the advancement of aquaculture. Fish requires a high protein level in feed for optimum growth performance (Deng et al., 2006). The importance of quality and quantity of feed is vital because it greatly influences the growth rate, survival, water, and fish production. Therefore, substantial struggles are required to regulate the quality and quantity of crude protein to maintain a high yield of fish (Das et al., 1991). Sound quality is a significant factor in the utilization of feed.

The criteria for the selection of artificial feed are (1) acceptability to fish, (2) effectiveness in promoting fish growth (3) degree of cheapness and availability of food. Determination of body composition through proximate analysis is essential to determine the optimum protein level and all other components in the fish feed (Waterman, 2000; Haider et al., 2016, 2021). In fish culture, the effectiveness of feed-in increasing fish growth does not rely only on the nutrients in the feed. Still, it is also greatly influenced by animal digestion and nutrients absorption present in feed. The utilization of all nutrients in fish relies on digestive enzymes' activity (Areekijseree et al., 2004; Iqbal et al., 2020b; Mehboob et al., 2017). The developmental stage of fish mainly affects fish's digestive enzyme activity (Falcón-Hidalgo et al., 2011; Hayat et al., 2020a). This helps formulate feed with balanced nutrients proving cost- effective (Tengjaroenkul et al., 2000). The gut is the first organ of fish where feed processes and different enzymes like acid protease (stomach), amylases (intestine) lipases, and alkaline proteases are secreted (Bakke et al., 2010). Enzyme activity is influenced by dietary protein levels (Buddington and Krogdahl, 2004). A slight alteration can optimize feed formulation in the enzymatic profile and concentration (Lundstedt et al., 2004; Iqbal et al., 2020b). So, it was necessary to evaluate different artificial feeds produced by various commercial aquafeed units in the country and their effect on growth parameters, proximate and intestinal enzymatic activities of rohu (Labeo rohita).

\section{Materials and Methods}

\subsection{Study area}

This study was directed in glass aquaria in the fish hatchery at the Department of Fisheries \& Aquaculture, UVAS (University of Veterinary and Animal Sciences), Ravi Campus, Pattoki. Pattoki is a city in the District Kasur, Punjab, Pakistan. It is situated at $31^{\circ} 1^{\prime} 0 \mathrm{~N} 73^{\circ} 50^{\prime} 60 \mathrm{E}$ with an altitude $(186 \mathrm{~m})$. The wind range at the north is $3 \mathrm{~km} / \mathrm{h}$, and the temperature remains at the range of $24.3^{\circ} \mathrm{C}$.

\subsection{Experimental design}

The experiment was performed in eight glass aquaria having dimensions $(\mathrm{L}=50.8 \mathrm{~cm}, \mathrm{~W}=25.4 \mathrm{~cm}$, and $\mathrm{H}=45.7 \mathrm{~cm}$ ) with a capacity of $50 \mathrm{~L}$. A group of 240 fish of Labeo rohita (rohu) having an average weight $(24.77 \pm 2.15 \mathrm{~g}$ ) was stocked in each aquarium. The fish was fed on commercially available feeds two times a day at 3\% feed of fish wet body weight. Treatment design was $T_{1}$ (Oryza Organics Pvt. Limited), $\mathrm{T}_{2}$ (AMG Feed Pvt. Limited), $\mathrm{T}_{3}$ (Aqua Feed Pvt. Limited), and $\mathrm{T}_{4}$ (Supreme Feed Pvt. Limited). Fish were taken on the basis of a complete randomized block design for further analysis in the laboratory. Physicochemical parameters were also measured on a weekly basis, following APHA (1998).

\subsection{Growth performance and analysis}

At the end of the feeding, the trial fish was weighed for calculation of percentage weight gain. A standard formula was calculated for the percentage weight gain, SGR\% (specific growth rate), and FCR (feed conversion ratio).

Net weight gain = Average final weight $(g)$ - Average initial weight $(\mathrm{g})$

$$
\begin{aligned}
& \text { Weight gain }(\%)=\frac{[\text { Final weight }(\mathrm{g})-\text { Initial weight }(\mathrm{g})]}{\text { Initial weight }(\mathrm{g})} \times 100 \\
& \text { Specific growth rate }(\mathrm{SGR} \%)=\frac{\left[\begin{array}{l}
\operatorname{In}(\text { Final wet body weight })- \\
\operatorname{In}(\text { Initial wet body weight })
\end{array}\right]}{\text { Number of days }} \times 100 \\
& \text { Feed conversion ratio }=\frac{\text { Feed Intake }(\mathrm{g})}{\text { Weight gain }(\mathrm{g})}
\end{aligned}
$$




\subsection{Proximate analysis}

After taking weight and length, fish samples were sacrificed by dipping in a water and clove oil solution. The samples were dried up for 24 hours in a hot air oven at $70{ }^{\circ} \mathrm{C}$ and grounded to make powder form. Kept in the refrigerator for further chemical analysis (crude protein \%, crude fat \%, dry matter \%, and ash content) by the methods of AOAC, (2006). Standard formulas were followed to calculate the Dry matter\%, Ash contents, Crude Protein and Crude fat. NFE (Nitrogen free extract) was estimated according to the subtraction method (Table 1). According to AOAC (2006), dry matter \% was measured using the following mathematical formula:

$$
\text { Dry Matter }(\%)=\frac{\text { Dry weight of Ether Extract }}{\text { Wet weight of sample }} \times 100
$$

$1 \mathrm{~g}$ of the sample was taken in pre-weighed crucible (W1, $\mathrm{W}_{2}$, and $\mathrm{W} 3_{3}$ ) and kept at $550^{\circ} \mathrm{C}$ for 4 to 6 hours. Then crucible was again held in a hot air oven, maintaining the temperature at $550{ }^{\circ} \mathrm{C}$ for 4 to 6 hours (AOAC 2006). The following formula was used to calculate the ash content.

$$
\text { Ash Contents }=\frac{\text { Difference in weight of ash }}{\text { Weight of sample }} \times 100
$$

Differences in weight of ash content $=\mathrm{W}_{3-} \mathrm{W}_{1}$

According to AOAC (2006), the Kjeldahl method was used to analyze the crude protein sample. $8 \mathrm{~g}$ of digestion mixture $\left(\mathrm{CuSO}_{4}\right.$ and $\left.\mathrm{K}_{2} \mathrm{SO}_{4}\right)$ and $20 \mathrm{ml}$ of concentrated $\mathrm{H}_{2} \mathrm{SO}_{4}$ were added to the sample to digest the sample. After dilution, the sample was distilled using $10 \mathrm{ml}$ of $0.5 \mathrm{~g}$ sodium hydroxide and Ammonium hydroxide containing $20 \mathrm{ml}$ of $4 \%$ of a boric acid solution. Finally, the titration of the sample was done with $\mathrm{N} / 10 \mathrm{H}_{2} \mathrm{SO}_{4}$, and reading was noted.

$$
\begin{gathered}
\mathrm{NH} 3=\frac{\text { Volume of } \mathrm{H} 2 \mathrm{SO} 4 \frac{\mathrm{N}}{10} \times 0.00014 \times \text { Volumeof diluted sample }}{\text { Volume of sample } \times \text { Dilute sample quantity }} \times 100 \\
\mathrm{~N}(\%)=\frac{(\mathrm{S}-\mathrm{B}) \times 0.014 \times \mathrm{D} \times 100}{\text { Weight of Sample }} \times \mathrm{V} \\
C P \%=6.25 \times \% \mathrm{~N}
\end{gathered}
$$

Where,

$\mathrm{N}=$ Normality of $\mathrm{HCL}, \mathrm{S}=$ Sample titration reading, $\mathrm{D}=$ Dilution of a sample after digestion, $B=$ Blank titration reading, $\mathrm{V}=$ Volume taken for distillation, 0.014= Milli equivalent weight of Nitrogen

By following the AOAC (2006) Soxhlet extraction apparatus, it was used to calculate fat contents \%. The following formula was used to calculate the crude fat $\%$ :

$$
\text { Crude fat }(\%)=\frac{\text { Weight of Ether Extract }}{\text { Weight of sample }} \times 100
$$

\subsection{Digestive enzyme assay}

\subsubsection{Sample preparation for assay of enzymes}

5-7 fish samples were taken randomly from each treatment, degutted, the intestine was removed, and mixed well in Tris $\mathrm{HCl}$ and homogenized at 6000rpm for 15min, and supernatant was removed (Bernfeld, 1955). $1 \mathrm{~mL}$ supernatant was incubated at $37^{\circ} \mathrm{C}$ after the addition of $2 \mathrm{~mL}$ starch phosphate buffer. After adding, $3 \mathrm{~mL}$ of DNS solution sample was again incubated and enzyme amylase was measured at an optical density of 540. Lipase activity was checked by protocols (Cherry and Crandell Junior, 1932). Fatty acids were estimated to maintain $\mathrm{pH}$. The reaction mixture including distilled water, tissue homogenate, olive oil emulsion, and phosphate buffer solution containing $\mathrm{pH} 7$ was well homogenated and kept at $4{ }^{\circ} \mathrm{C}$ for 24 hrs. Further titration was done using Phenolphthalein indicator (2-3 drops) and alcohol (95\%). The activity of the enzyme was measured by the amount of alkali consumed. Protease activity was evaluated by using one percent azocasein in fifty $\mathrm{mmol}$ in tris $\mathrm{HCl}$ and pH was maintained at 7.5 (Garcia-Carreno, 1992).

\subsection{Statistical analysis}

The impact of four commercial fish feed on growth, proximate composition, and enzymatic activities were analyzed through a one-way ANOVA technique. The General Linear Model procedure was applied by SAS software (version 9.1). Means of Significant treatment were isolated through DMRT (Duncan's Multiple Range Test). Data were represented as mean \pm standard errors, and the following mathematical model was employed:

$$
Y_{i j}=\mu+\tau_{i}+\epsilon_{i j}
$$

Where,

$Y_{i j}=$ Observation of dependent variable recorded on $i^{\text {th }}$ treatment

$\mu=$ Population mean

Table 1. Proximate analysis of experimental diets.

\begin{tabular}{ccccccc}
\hline $\begin{array}{c}\text { Experimental } \\
\text { Diets }\end{array}$ & DM (\%) & M (\%) & CP (\%) & CF (\%) & CBF (\%) & Ash (\%) \\
\hline Oryza & 92.2 & 7.8 & 25.20 & 3.12 & 9.45 & 20.2 \\
AMG & 93.1 & 6.9 & 22.20 & 4.44 & 8.38 & 23.6 \\
Aqua & 91.7 & 8.3 & 24.23 & 6.63 & 6.97 & 27.8 \\
Supreme & 94.8 & 5.2 & 22.40 & 4.44 & 8.38 & 25.8 \\
\hline
\end{tabular}

$\mathrm{DM}=$ Dry Matter; $\mathrm{M}=$ Moisture; $\mathrm{CP}=$ Crude Protein; $\mathrm{CF}=$ Crude Fat; $\mathrm{CFB}=$ Crude Fiber. 
$\tau_{\mathrm{i}}=$ Effect of $\mathrm{i}^{\text {th }}$ treatment $(\mathrm{i}=1,2,3,4)$

$\epsilon_{\mathrm{ij}}=$ Residual effect of $\mathrm{j}^{\text {th }}$ observation on $\mathrm{i}^{\text {th }}$ treatment NID $\sim 0, \sigma^{2}$

\section{Results}

\subsection{Growth parameters}

The results of all the growth parameters are presented in Table 2. The initial weight of stocking fish (Labeo rohita) showed non-significant. The treatment T1 (38.20 \pm 0.07$)$ displayed the highest weight gain significantly as compared to all other treatments T2 $(34.60 \pm 0.01), \mathrm{T} 3(33.95 \pm 0.26)$, and T4 (36.57 \pm 0.15$)$. Treatment T4 (36.57 \pm 0.15$)$ showed significantly higher weight gain when compared to $\mathrm{T} 2$ and T3. Treatment T1 $(14.00 \pm 0.03)$ showed the highest net weight gain as compared to other treatments T2 $(9.82 \pm 0.42)$, T3 $(9.89 \pm 0.29)$, and T4 (36.57 \pm 0.15$)$. T4 (11.85 \pm 0.09$)$ showed significantly high net weight gain when it compared T2 and T3. Net weight gain of T2 $(9.82 \pm 0.42)$ and T3 $(9.89 \pm 0.29)$ were non-significant. Treatment T1 (57.86 \pm 0.36$)$ showed the highest percentage weight gain significantly as compared to the other three treatments T2 $(40.17 \pm 2.43)$, T3 (41.15 \pm 1.24$)$, and T4 (47.94 \pm 0.23$)$. Treatment T4 showed the highest percentage weight gain significantly as compared to $\mathrm{T} 2$ and T3. Treatment T2 $(40.17 \pm 2.43)$ and treatment T3 $(41.15 \pm 1.24)$ were non-significant in percent weight gain. FCR was recorded significantly in T1 $(1.06 \pm 0.04)$ compared to T3 $(1.34 \pm 0.03)$. In treatment T4 $(1.20 \pm 0.002)$, FCR was exceptionally higher than $\mathrm{T} 2(1.40 \pm 0.01)$. The lowest value of FCR was recorded in T1 (1.06 \pm 0.04$)$, which is best. The highest SGR value (specific growth rate) was observed in $\mathrm{T} 1(0.50 \pm 0.02)$ and significantly different from other treatments. The low-value SGR (specific growth rate) was observed in T2 $(0.37 \pm 0.13)$, and T3 $(0.35 \pm 0.067361)$. In treatment 44 the value-specific growth rate $(0.43 \pm 0.01)$ was observed average as compared to other treatments shown in Table 2.

\subsection{Body composition}

The results on fish proximate composition analysis are presented in Table 3. The values of dry matter\% were observed non-significant $(p>0.05)$ in each treatment and pretreated fish. The maximum value of crude protein was observed in $\mathrm{T} 1(17.47 \pm 0.27)$ that was significantly different from initial and other treatment values. The values for crude protein\% in all other treatments were non-significant. The values of crude fat were observed highest in T2 (4.02 \pm 0.04$)$ and T3 (3.86 \pm 0.08$)$, respectively, and significantly different from all other treatments. In treatment $\mathrm{T} 4$ value of crude fat significantly ( $3.13 \pm 0.12)$ higher than treatment T1 and Initial value. In $\mathrm{T} 1$, crude fat value $(3.60 \pm 0.11)$ was significantly different from the initial value. The highest ash value was observed in the initial fish ( $4.80 \pm 0.25)$ significantly different from all other treatments. The value of ash in treatment T4 (3.82 \pm 0.14$)$ was recorded as high compared to other treatments. Among treatment T2 $(3.15 \pm 0.32)$ and T3 (3.27 \pm 0.12 ), values of ash, respectively, were found non-significant. The lowest value of ash $(2.79 \pm 0.14)$ was observed in treatment $\mathrm{T} 1$ and significantly differed from other treatments. The value of nitrogen-free extract was observed highest in T3 $(2.34 \pm 0.05)$ and T4 (2.78 \pm 0.36$)$ significantly different from other therapies. In initial fish $(2.13 \pm 0.11)$ and treatment T1 $(1.63 \pm 0.20)$ value of

Table 2. Growth parameters of rohu (Labeo rohita) among different treatments.

\begin{tabular}{|c|c|c|c|c|c|}
\hline $1,058 \mathrm{~mm}$ & T1 & T2 & T3 & T4 & P-value \\
\hline Initial Weight (g) & $24.77 \pm 0.44$ & $24.20 \pm 0.10$ & $24.05 \pm 0.03$ & $24.72 \pm 0.06$ & NS \\
\hline Final Weight (g) & $38.20 \pm 0.07^{\mathrm{a}}$ & $34.60 \pm 0.01^{c}$ & $33.95 \pm 0.26^{c}$ & $36.57 \pm 0.15^{\mathrm{b}}$ & * \\
\hline Net weight gain (g) & $14.00 \pm 0.03^{\mathrm{a}}$ & $9.82 \pm 0.42^{\mathrm{c}}$ & $9.89 \pm 0.29^{c}$ & $11.85 \pm 0.09^{\mathrm{b}}$ & $* *$ \\
\hline Weight gain (\%) & $57.86 \pm 0.36^{a}$ & $40.17 \pm 2.43^{c}$ & $41.15 \pm 1.24^{\mathrm{c}}$ & $47.94 \pm 0.23^{b}$ & $* *$ \\
\hline FCR & $1.06 \pm 0.04^{\mathrm{a}}$ & $1.40 \pm 0.01^{c}$ & $1.34 \pm 0.03^{\mathrm{a}}$ & $1.20 \pm 0.002^{\mathrm{b}}$ & $*$ \\
\hline SGR (\%) & $0.50 \pm 0.02^{\mathrm{a}}$ & $0.37 \pm 0.13^{c}$ & $0.35 \pm 0.07^{c}$ & $0.43 \pm 0.01^{\mathrm{ab}}$ & $*$ \\
\hline
\end{tabular}

Different superscript within row differ significantly, NS = Non-significant, ${ }^{*}=\mathrm{P} \leq 0.01 ;{ }^{* *}=\mathrm{P} \leq 0.001$.

Table 3. Proximate composition of rohu (Labeo rohita) fed with four different commercial diets.

\begin{tabular}{|c|c|c|c|c|c|c|}
\hline Treatments & Initial & T1 & T2 & T3 & T4 & P-value \\
\hline Dry matter \% & $23.02 \pm 0.02^{\mathrm{a}}$ & $25.50 \pm 0.035^{\mathrm{a}}$ & $25.50 \pm 0.04^{\mathrm{a}}$ & $25.97 \pm 0.10^{\mathrm{a}}$ & $26.23 \pm 0.16^{\mathrm{a}}$ & $* *$ \\
\hline Crude Protein \% & $13.69 \pm 0.30^{\mathrm{b}}$ & $17.47 \pm 0.27^{\mathrm{a}}$ & $16.29 \pm 0.10^{\mathrm{b}}$ & $16.50 \pm 0.25^{\mathrm{b}}$ & $16.48 \pm 0.06^{\mathrm{b}}$ & $* * *$ \\
\hline Crude Fat \% & $2.40 \pm 0.04^{c}$ & $3.60 \pm 0.11^{\mathrm{ab}}$ & $4.02 \pm 0.04^{\mathrm{a}}$ & $3.86 \pm 0.08^{\mathrm{a}}$ & $3.13 \pm 0.12^{b}$ & $* *$ \\
\hline Ash \% & $4.80 \pm 0.25^{\mathrm{a}}$ & $2.79 \pm 0.14^{\mathrm{d}}$ & $3.15 \pm 0.32^{c}$ & $3.27 \pm 0.12^{\mathrm{c}}$ & $3.82 \pm 0.14^{\mathrm{b}}$ & $* *$ \\
\hline $\begin{array}{l}\text { Nitrogen free } \\
\text { Extract }\end{array}$ & $2.13 \pm 0.11^{b}$ & $1.63 \pm 0.20^{\mathrm{b}}$ & $2.25 \pm 0.28^{\mathrm{ab}}$ & $2.34 \pm 0.05^{\mathrm{a}}$ & $2.78 \pm 0.36^{a}$ & $*$ \\
\hline
\end{tabular}

Different superscript within row differ significantly, ${ }^{*}=\mathrm{P} \leq 0.05 ;{ }^{* *}=\mathrm{P} \leq 0.01 ;{ }^{* * *}=\mathrm{P} \leq 0.001$. 
Table 4. Digestive enzyme activity of Labeo rohita fed with four different commercial feeds

\begin{tabular}{cccccc}
\hline Treatments & T1 & T2 & T3 & T4 & P-value \\
\hline Amylase (mg protein) & $14.34 \pm 0.06^{\mathrm{a}}$ & $13.27 \pm 0.10^{\mathrm{b}}$ & $12.26 \pm 0.30^{\mathrm{c}}$ & $13.11 \pm 0.29^{\mathrm{b}}$ & $*$ \\
Protease (ml enzyme) & $15.09 \pm 0.03^{\mathrm{a}}$ & $13.21 \pm 0.05^{\mathrm{b}}$ & $10.19 \pm 0.32^{\mathrm{c}}$ & $11.75 \pm 0.36^{\mathrm{c}}$ & $* *$ \\
Lipase (ml enzyme) & $0.82 \pm 0.004^{\mathrm{a}}$ & $0.77 \pm 0.01^{\mathrm{b}}$ & $0.80 \pm 0.01^{\mathrm{a}}$ & $0.80 \pm 0.002^{\mathrm{a}}$ & $*$ \\
\hline
\end{tabular}

Different superscript within row differ significantly, ${ }^{*}=\mathrm{P} \leq 0.01 ;{ }^{* *}=\mathrm{P} \leq 0.001$.

nitrogen-free extract respectively was the same; however, significantly different from treatment T2 (2.25 \pm 0.28$)$.

\subsection{Enzyme activity}

The results of the digestive enzyme activity are represented in Table 4 . The amylase activity was observed highest in T1 (14.34 \pm 0.06$)$ and significantly different from other treatments. In treatment T2 and T4 values of amylase activity were non-significant $(13.27 \pm 0.10)$ (13.11 \pm 0.29$)$, however high than T3 (12.26 \pm 0.30$)$. Protease activity was also observed highest in treatment $\mathrm{T} 1(15.09 \pm 0.03)$ compared to other treatments. In treatment T2 (13.21 \pm 0.05$)$, protease activity was observed highest compared to T3 and T4. In treatment T3 $(10.19 \pm 0.32)$ and $\mathrm{T} 4$ (11.75 \pm 0.36$)$, protease enzyme activity was observed non-significant. Lipase activity in T1, T2, and T4 is the same; however, significantly higher than T2.

Analysis of variance of all the parameters are presented in Table 5.

\section{Discussion}

In aquaculture, the main issue is to manage the connection between high growth rate and feed utilization. Fish nutrition is a critical factor in this field because its feed cost is compared with total yield (Craig and Helfrich, 2002). The study was steered to assess the impact of various commercial feeds on growth parameters, proximate composition, and rohu enzyme examination.

In this study, significantly higher growth was found in fingerlings of Labeo rohita in the treatment group $\mathrm{T} 1(\mathrm{CP}=25.20)$ in the comparison of $\mathrm{T} 2, \mathrm{~T} 3$, and $\mathrm{T} 4$. Rohu gained a higher weight in treatment T1 $\left(14.00 \pm 0.03^{\mathrm{a}}\right)$. In treatment $\mathrm{T} 4$ the weight gain of rohu fingerling was lower $\left(11.85 \pm 0.09^{\mathrm{b}}\right)$ than treatment T1. Lesser weight gain was observed in the T2, but is slightly higher than T3. FCR ratio $\left(1.06 \pm 0.04^{\mathrm{a}}\right)$ was also recorded best in the T1 fingerlings. Simultaneously, a higher FCR $\left(1.40 \pm 0.01^{\mathrm{c}}\right)$ was recorded in the T2, which is not the best ratio for fish farmers. In SGR, it was recorded significantly higher in fingerlings of treatment T1 $\left(0.50 \pm 0.02^{\mathrm{a}}\right)$. In contrast, T4 showed higher SGR $\left(0.43 \pm 0.01^{\mathrm{ab}}\right)$ as compared to treatment T2 and T3. Similarly, T2 Showed higher SGR $\left(0.37 \pm 0.13^{c}\right)$ than T3. Overall, T3 showed lesser SGR $\left(0.35 \pm 0.07^{c}\right)$. These results correlated with the study of (Ahmed et al. 2012), who investigated the effect of three feeds [T1 (control), T2 (Miracle), and T3 (Tokyo)] with varying levels of proteins. Their study showed the higher weight gain $(383.88 \pm 1.8)$ for Labeo rohita fed in T3 (Tokyo) treatment, which was significantly increased. T1 (control) treatment showed
Table 5. Analysis of Variance of different parameters.

\begin{tabular}{crr}
\hline Growth Parameters & F Value & Pr $>$ F \\
\hline Initial Weight $(\mathrm{g})$ & 0.14 & 0.9356 \\
Final Weight $(\mathrm{g})$ & 56.41 & $<0.0001$ \\
Net weight gain $(\mathrm{g})$ & 8.26 & 0.0006 \\
Weight gain $(\%)$ & 22.10 & $<0.0001$ \\
FCR & 9.51 & 0.0003 \\
SGR (\%) & 5.98 & 0.0034 \\
Proximate Composition & & \\
Dry matter \% & 57.75 & $<0.0001$ \\
Crude Protein \% & 28.78 & $<0.0001$ \\
Crude Fat \% & 20.06 & $<0.0001$ \\
Ash \% & 2.97 & 0.0351 \\
Nitrogen free Extract & 9.17 & $<0.0001$ \\
Digestive Enzyme Activity & & \\
Amylase (mg protein) & 13.27 & $<0.0001$ \\
Protease (ml enzyme) & 29.76 & $<0.0001$ \\
Lipase (ml enzyme) & 6.41 & 0.0024 \\
\hline
\end{tabular}

lesser weight as compared to T2 (Miracle). FCR value was found to be best in treatment T3 as compared to T1 and T2. Similarly, our findings relate to the results of (Kumar et al. 2011), in which they fed the Labeo rohita on varying levels [T1 (20\%), T2 (25\%) T3 (30\%)] of protein. T2 group showed higher weight gain $\left(183.29^{\mathrm{b}}\right)$ and best FCR value ( $1.43^{\mathrm{a}}$ ) in the fingerlings of Labeo rohita. The SGR rate was also found to be highest (3.21b) in the T2 group compared to other treatment groups. Following the work of Daudpota et al. (2014), the growth performance of the fingerlings of tilapia was found to be significantly fed with the dietary protein level. Varying protein levels (25\%, 30\%, $35 \%$, and $40 \%$ ) experimented on tilapia. The tilapia fed on $35 \%$ and $40 \%$ protein level showed significant $(P<0.05)$ growth performance. Weight gain SGR and FCR of tilapia fed on the $35 \%$ and $40 \%$ were $470.0 \pm 3.2 \mathrm{c}$ and $480.0 \pm 3.0 \mathrm{c}$, $4.14 \pm 0.05 \mathrm{c}$ and $4.18 \pm 0.05 \mathrm{c}, 3.32 \pm 0.4 \mathrm{~b}$ and $3.27 \pm 0.3 \mathrm{~b}$ respectively. In the enzymatic activity, the T1 treatment group showed the highest values of enzymes compared to other treatment groups. There were higher amylase values in our investigations; protease and lipase enzymes were $14.34 \pm 0.06,15.09 \pm 0.03$, and $0.82 \pm 0.004$ activity in the fingerlings of rohu, respectively. According to the results of (Kumar et al., 2011), protease activity was found to be significantly higher in the fish fed in the treatment group 
$\mathrm{T} 2$ compared to other treatment groups (T3, $\mathrm{T} 1$, and $\mathrm{T} 0$ ). The activity of higher in the intestinal portion of the fish body. Our results are in accordance with another study conducted by (Bazaz and Keshavanath, 1993), in which they reported similar results about the enzymatic activity of Catla catla and mahseer species of fish. Dietary levels are found to affect the protease activity of fish bodies in the intestinal segment (Phadate, 1987; Gangadhar et al., 1997). Amylase enzyme and lipase enzyme concentration were high in the rohu treated in the treatment group T1. Gangadhar et al. (1997) intimated the higher lipase enzyme activity in the Labeo rohita fed on the $25 \%$ protein level. Similarly, findings were encountered by Nandeesha et al. (1994) in the body of the stunted year of rohu (Labeo rohita).

The increase in the dietary protein level can enhance the protein level in the fish body. In rohu's body composition, the crude protein level is enhanced by increasing the dietary protein level. In our results, T1 treatment groups showed the higher Crude $\left(17.47 \pm 0.27^{\mathrm{a}}\right)$ protein in the fingerlings of Labeo rohita as compared to other treatment groups T2 $\left(16.29 \pm 0.10^{\mathrm{b}}\right)$, T3 $\left(16.50 \pm 0.25^{\mathrm{b}}\right)$, and T4 $\left(16.48 \pm 0.06^{\mathrm{b}}\right)$. Similarly, the results of (De Borba et al., 2003, Siddiqui and Khan 2009) were in accordance with our experiment results. Their results also evidenced that the increase in the dietary level of protein can enhance the fish's body crude protein level. The lipids content in the diet is the critical source of energy for the fish body. Rohu fed on the highest dietary lipid content showed the most elevated crude lipids in the body. Rohu fed on diet with $4.44 \%$ crude fat showed a higher fat content level (16.29 $\pm 0.10^{\mathrm{b}}$ $\%$ ) in the body composition. According to the results of Lin (1997), the crude lipids in the fish body are elevated by the increase in the dietary level of crude fat.

\section{Conclusions}

It was concluded that the comparison of different commercial fish feeds that the Oryza feed with $25 \%$ protein showed significant growth and high protease enzyme activity. This study helps the feeding of fish for farmers in the selection of the best quality feed. Based on this study, it is suggested that Oryza having $25 \%$ crude protein feed is best to achieve optimum growth and crude protein level in fish (Labeo rohita). It is recommended that farmers use this feed to get optimum yield without disturbing the physicochemical parameters of water.

\section{Acknowledgements}

The authors extend their sincere thanks to the Department of Fisheries and Aquaculture, University of Veterinary and Animal Sciences (Ravi Campus Pattoki), Lahore, Pakistan, to provide financial support to complete the research trial.

\section{References}

ACKEFORS, H., HUNER, J.V. and KONIKOFF, M., 1994. Food products press. Philadelphia: Haworth Press.
AHMAD, S., HERA, Z., HANIF, M.S., and SYED, A.H., 2020. Effects of carbosulfan on the biology of bird cherry oat aphid. Biological and Clinical Sciences Research Journal, vol. 2020, no. 1, pp. e014.

AHMED, M.S., SHAFIQ K. and KIANI, M.S., 2012. Growth performance of major carp, Labeo rohita fingerlings on commercial feeds. Journal of Animal and Plant Sciences, vol. 22, no. 1, pp. 93-96.

AMERICAN PUBLIC HEALTH ASSOCIATION - APHA, 1998. Standard methods for the examination of water and wastewater. USA: APHA.

AREEKIJSEREE, M., ENGKAGUL, A., KOVITVADHI, U., THONGPAN, A., MINGMUANG, M., PAKKONG, P. and RUNGRUANGSAKTORRISSEN, K., 2004. Temperature and pH characteristics of amylase and proteinase of adult freshwater pearl mussel, Hyriopsis (Hyriopsis) bialatus Simpson 1900. Aquaculture (Amsterdam, Netherlands), vol.234, no. 1-4, pp. 575-587. http:// dx.doi.org/10.1016/j.aquaculture.2003.12.008.

ASSOCIATION OF OFFICIAL ANALYTICAL CHEMISTS - AOAC, 2006. Official methods of analysis. 18th ed. Gaithersburgs, MD: AOAC.

ATIQUE, U., IQBAL, S., KHAN, N., QAZI, B., JAVEED, A., ANJUM, K.M., HAIDER, M.S., KHAN, T.A., MAHMOOD, S. and SHERZADA, S., 2020a. Multivariate assessment of water chemistry and metals in a river impacted by tanning industry. Fresenius Environmental Bulletin, vol. 29, pp. 3013-3025.

BAE, D.-Y., ATIQUE, U., YOON, J., LIM, B. and AN, K.-G., 2020. Ecological risk assessment of urban streams using fish biomarkers of DNA damages and physiological responses. Polish Journal of Environmental Studies, vol. 29, no. 2, pp. 1-10. http://dx.doi. org/10.15244/pjoes/104660.

BAKKE, A.M., GLOVER, C. and KROGDAHL, A., 2010. Feeding, digestion and absorption of nutrients. Fish Physiology, vol. 30, pp. 57-110. http://dx.doi.org/10.1016/S1546-5098(10)03002-5.

BATOOL, S.S., KHAN, N., ATIQUE, U., AZMAT, H., IQBAL, K.J., MUGHAL, D.H., AHMAD, M.S., BATOOL, S., MUNAWAR, S., DOGAR, S., NAWAZ, M., and AMJAD, S., 2018. Impact of azomite supplemented diets on the growth and body composition of catfish (Pangasius hypophthalmus). Pakistan Journal of Zoology, no. 13, suppl. ser, pp. 8-12.

BAZAZ, M.M. and KESHAVANATH, P., 1993. Effect of feeding different levels of sardine oil on growth, muscle composition and digestive enzyme activities of mahseer, Tor khudree. Aquaculture (Amsterdam, Netherlands), vol. 115, no. 1-2, pp. 111-119. http://dx.doi.org/10.1016/0044-8486(93)90362-3.

BERNFELD, P., 1955. Amylases, $\alpha$ and $\beta$. Methods in Enzymol. New York: Academic Press, pp. 149-158.

BUDDINGTON, R.K. and KROGDAHL, A., 2004. Hormonal regulation of the fish gastrointestinal tract. Comparative Biochemistry and Physiology. Part A, Molecular E'Integrative Physiology, vol. 139, no. 3, pp. 261-271. http://dx.doi.org/10.1016/j.cbpb.2004.09.007. PMid: 15556381.

CHERRY, I.S. and CRANDELL JUNIOR, L.A., 1932. The specificity of pancreatic lipase: its appearance in the blood after pancreatic injury. The American Journal of Physiology, vol. 100, no. 2, pp. 266-273. http://dx.doi.org/10.1152/ajplegacy.1932.100.2.266.

CRAIG, S. and HELFRICH, L.A., 2002. Understanding fish nutrition, feeds, and feeding. Virginia Cooperative Extension, vol. 63, pp. $256-270$.

DAS, K., MOHANTY, S. and SARKAR, S., 1991. Optimum dietary protein to energy ratio for Labeo rohita fingerlings. Manila, Philippines: Asian Fisheries Society, pp. 69-73.

DAUDPOTA, A.M., SIDDIQUI, P.J.A., ABBAS, G., NAREJO, N.T., SHAH, S.S.A., KHAN, N., and DASTAGIR, G., 2014. Effect of dietary protein level on growth performance, protein utilization and body composition of Nile tilapia cultured in low salinity water. 
International Journal of Interdisciplinary and Multidisciplinary Studies (IJIMS), vol. 2, no. 2, pp. 135-147.

DEBORBA, M., FRACALOSSI, D., PEZZATO, L., MENOYO, D. and BAUTISTA, J., 2003. Growth, lipogenesis and body composition of piracanjuba (Brycon orbignyanus) fingerlings fed different dietary protein and lipid concentrations. Aquatic Living Resources, vol. 16, no. 4, pp. 362-369. http://dx.doi.org/10.1016/S09907440(03)00061-5.

DENG, J., MAI, K., AI, Q., ZHANG, W., WANG, X., XU, W. and LIUFU, Z., 2006. Effects of replacing fish meal with soy protein concentrate on feed intake and growth of juvenile Japanese flounder, Paralichthys olivaceus. Aquaculture, vol. 258, no. 1-4, pp. 503-513. http://dx.doi.org/10.1016/j.aquaculture.2006.04.004.

FALCÓN-HIDALGO, B., FORRELLAT-BARRIOS, A., CARRILLO FARNÉS, O. and UBIETA HERNÁNDEZ, K., 2011. Digestive enzymes of two freshwater fishes (Limia vittata and Gambusia punctata) with different dietary preferences at three developmental stages. Comparative biochemistry and physiology. Part B, Biochemistry E' molecular biology, vol. 158, no. 2, pp. 136-141. http://dx.doi. org/10.1016/j.cbpb.2010.10.009. PMid:21044696.

FOOD AND AGRICULTURE ORGANIZATION - FAO, 2009 [viewed 29 March 2021]. Fisheries glossary [online]. Rome: FAO. Available from: www.fao.org/fi/glossary/default.asp

GANGADHAR, B., NANDEESHA, M.C., VARGHESE, T.J. and KESHAVANATH, P., 1997. Effect of varying protein and lipid levels on the growth of rohu, Labeo rohita. Asian Fisheries Science, vol. 10, pp. 139-147.

GARCIA-CARRENO, F.L., 1992. The digestive proteases of langostilla (pleuroncodes planipes, decapoda): their partial characterization, and the effect of feed on their composition. Comparative Biochemistry and Physiology, vol. 103, no. 3, pp. 575-578. http:// dx.doi.org/10.1016/0305-0491(92)90373-Y.

GAUQUELIN, F., CUZON, G., GAXIOLA, G., ROSAS, C., ARENA, L., BUREAU, D.P. and COCHARD, J.C., 2007. Effect of dietary protein level on growth and energy utilization by Litopenaeus stylirostris under laboratory conditions. Aquaculture (Amsterdam, Netherlands), vol. 271, no. 1-4, pp. 439-448. http://dx.doi. org/10.1016/j.aquaculture.2006.05.062.

HAIDER, M.S., ASHRAF, M., AZMAT, H., KHALIQUE, A., JAVID, A. ATIQUE, U., ZIA, M., IQBAL, K.J. and AKRAM, S., 2016. Nutritive evaluation of fish acid silage in Labeo rohita fingerlings feed. Journal of Applied Animal Research, vol. 44, no. 1, pp. 158-164. http://dx.doi.org/10.1080/09712119.2015.1021811.

HAIDER, M.S., JAVID, A., AZMAT, H., ABBAS, S., ASHRAF, S., ALTAF, M., ATIQUE, U., IQBAL, S., IQBAL, K.J., and BAOOL, M., 2018. Effect of processed fish waste on growth rate and digestive enzymes activities in Cyprinus carpio. Pakistan Journal of Zoology, vol. 13, suppl. ser., pp. 191-198.

HAIDER, M.S., SHABANA, T., IQBAL, S., ATIQUE, U., ALTAF, M., NISA, Q., SHARIF, B., AMJAD, N., ULLAH, S., IQBAL, A. and ASLAM, K., 2021. Comparative impact assessment of varying salinity concentration on growth, survival and blood chemistry of tilapia fingerlings. Survey in Fisheries Sciences, vol. 7, pp. 111126. http://dx.doi.org/10.18331/SFS2021.7.3.9.

HASAN, M., 2001. Nutrition and feeding for sustainable aquaculture development in the third millennium. In: Aquaculture in the Third Millennium. Technical Proceedings of the Conference on Aquaculture in the Third Millennium, 20-25 February 2000, Bangkok, Thailand. Rome: FAO, pp. 193-219.

HAYAT, S., NAEEM, M., RAMZAN, M., ZAFARULLAH, M., AHMAD, I., ALI, Q. and MALIK, A., 2020a. Study on zooplankton diversity during spring season in Chashma Lake, Pakistan. Biological and
Clinical Sciences Research Journal, vol. 2020, pp. e009. http:// dx.doi.org/10.47264/bcsrj0101009.

HAYAT, S., RAMZAN, M., ZAFARULLAH, M., AHMAD, I., ALI, Q. and MALIK, A., 2020b. Conservation of an endangered carnivorous fish rita rita through induced breeding. Biological and Clinical Sciences Research Journal, vol. 2020, pp. e004. http://dx.doi. org/10.47264/bcsrj0101004.

IQBAL, K.J., JAVID, A., KHAN, N., BABOO, I., ALI, A., MOHSIN, K., ANWER, A., ATIQUE, U., ALTAF, M., HUSSAIN, D. and CHAUDHRY, A., 2020. Consumer attitude towards wild-caught and farmraised fish in Bahawalpur. Biologia, vol. 66, pp. 11-17.

IQBAL, S., ATIQUE, U., MAHBOOB, S., HAIDER, M.S., IQBAL, H.S., AL-GHANIM, K.A., AL-MISNED, F., AHMED, Z., and MUGHAL, M.S., 2020b. Effect of supplemental selenium in fish feed boosts growth and gut enzyme activity in juvenile tilapia (Oreochromis niloticus). Journal of King Saud University - Science, vol. 32, no. 5, pp. 2610-2616. http://dx.doi.org/10.1016/j.jksus.2020.05.001.

IQBAL, S., ATIQUE, U., MUGHAL, M.S., YOUNUS, M., RAFIQUE, M.K., HAIDER, M.S., IQBAL, H.S., SHERZADA, S. and KHAN, T.A., 2020a. Selenium-Supplemented Diet Influences Histological Features of Liver and Kidney in Tilapia (Oreochromis niloticus). Jordan Journal of Biological Sciences, vol. 13, pp. 453-461.

JEWEL, M.A.S., M. W. ALI, S., HAQUE, M.A., U. AHMED, M.G., IQBAL, S., ATIQUE, U., PERVIN, M.E. and K. PAUL, A., 2020. Growth and economics of silver barb (Barbonymus gonionotus) in ricefish-vegetable integrated culture system at different stocking densities in a rainfed arid zone. Egyptian Journal of Aquatic Biology and Fisheries, vol. 24, no. 6, pp. 459-476. http://dx.doi. org/10.21608/ejabf.2020.117948.

KHAN, N., ATIQUE, U., ASHRAF, M., MUSTAFA, A., MUGHAL, M.S., RASOOL, F., AZMAT, H., TAYYAB, M., and IQBAL, K.J., 2018. Effect of various protein feeds on the growth, body composition, hematology and endogenous enzymes of catfish (Pangasius hypophthalmus). Pakistan Journal of Zoology, vol. 13, suppl. ser., pp. 112-119.

KUMAR, R.V., RAMESH, K.S., PATIL, P., KUMAR, B., and MANISSERY, J.K., 2011. Dietary protein requirement of stunted fingerlings of rohu, Labeo rohita (Hamilton) during grow-out stage. Indian Journal of Fisheries, vol. 58, no. 4, pp. 49-53.

LIN, S., 1997. Effect of dietary lipid and Astaxanthin level on pigmentation of arctic char (salvelinus alpinus). Newfoundland and Labrador: Memorial University of Newfoundland.

LUNDSTEDT, L.M., MELO, J.F.B. and MORAES, G., 2004. Digestive enzymes and metabolic profile of Pseudoplatystoma corruscans (Teleostei: Siluriformes) in response to diet composition. Comparative Biochemistry and Physiology. Part B, Biochemistry E'Molecular Biology, vol. 137, no. 3, pp. 331-339. http://dx.doi. org/10.1016/j.cbpc.2003.12.003. PMid:15050520.

LUO, Z., LIU, Y., MAI, K., TIAN, L., LIU, D. and TAN, X., 2004. Optimal dietary protein requirement of grouper Epinephelus coioides juveniles fed isoenergetic diets in floating net cages. Aquaculture Nutrition, vol. 10, no. 4, pp. 247-252. http://dx.doi. org/10.1111/j.1365-2095.2004.00296.x.

MEHBOOB, A., KHAN, N., ATIQ, U., IQBAL, K.J., TAYYAB, R., BATOOL, S.S., BATOOL, H.S., AMJAD, S. and TANVEER, M., 2017. Effect of fenugreek as a feed additive on the growth, body composition and apparent nutrients digestibility of striped catfish Pangasius hypophthalmus fry. Pakistan Journal of Zoology, vol. 49, no. 6, pp. 2037-2042. http://dx.doi.org/10.17582/journal. pjz/2017.49.6.2037.2042.

NANDEESHA, M.C., DATHATHRI, K., KRISHNAMURTHY, D., VARGHESE, T.J., GANGADHAR, B. and UMESH, N.R., 1994. Effect of varied levels of protein on growth and tissue biochemistry of stunted 
yearlings of rohu, Labeo rohita, in the absence and presence of natural food. In: S.S. SILVA, Ed. Fish Nutrition Research in Asia, Proceedings of the fifth Asian fish nutrition workshop. Manila, Philippines: Asian Fisheries Society Special Publication. pp. 93-100.

PHADATE, S.V., 1987. Investigations on the digestive enzymes of some cultivable freshwater fishes. India, Bangalore: University of Agricultural Sciences, 148 p. Master's Dissertation in Fish Resources and Aquaculture. Thesis.

RAHMAN, M.M., HAQUE, S.M., ISLAM, M.A., PAUL, A.K., IQBAL, S., ATIQUE, U., WAHAB, A., EGNA, H. and BROWN, C., 2020. Assessment of mud crab fattening and culture practices in coastal Bangladesh: understanding the current technologies and development. Aquaculture, Aquarium, Conservation $\mathcal{E}$ Legislation, vol. 13, pp. 582-596.

RAY, S., MONDAL, P., PAUL, A.K., IQBAL, S., ATIQUE, U., ISLAM, M.S., MAHBOOB, S., AL-GHANIM, K.A., AL-MISNED, F. and BEGUM, S., 2021. Role of shrimp farming in socio-economic elevation and professional satisfaction in coastal communities of Southern Bangladesh. Aquaculture Reports, vol. 20, pp. 100708. http:// dx.doi.org/10.1016/j.aqrep.2021.100708.

SIDDIQUI, T.Q. and KHAN, M.A., 2009. Effects of dietary protein levels on growth, feed utilization,protein retention efficiency and body composition of young Heteropneustes fossilis (Bloch). Fish Physiology and Biochemistry, vol. 35, no. 3, pp. 479-488. http://dx.doi.org/10.1007/s10695-008-9273-7. PMid:18998230.

TENGJAROENKUL, B., SMITH, B.J., CACECI, T. and SMITH, S.A., 2000. Distribution of intestinal enzyme activities along the intestinal tract of cultured Nile tilapia, Oreochromis niloticus L. Aquac, vol. 182, no. 3-4, pp. 317-327. http://dx.doi.org/10.1016/S00448486(99)00270-7.

WATERMAN, J.J., 2000. Composition and quality of fish. Edinburgh: Torry Research Station.

WEBSTER, C.D. and LIM, L., 2002. Nutrient requirements and feeding of finfish for aquaculture. Wallingford, UK: CABI Publishing. 